Barhamudin dan Abuyazid Bustomi, Perluasan Kompetensi Peradilan Tata Usaha Dalam Undang-Undang Administrasi Pemerintahan, Halaman 1-16

\title{
PERLUASAN KOMPETENSI PERADILAN TATA USAHA DALAM UNDANG-UNDANG ADMINISTRASI PEMERINTAHAN
}

\author{
Barhamudin $^{1}$ dan Abuyazid Bustomi ${ }^{2}$ \\ ${ }^{1}$ Fakultas Hukum, Universitas Palembang \\ E-mail : Barigama@gmail.com \\ ${ }^{2}$ Fakultas Hukum, Universitas Palembang \\ E-mail : abuyazid.bustomi13.ab@gmail.com
}

\begin{abstract}
The purpose of this study is to explain the field of State Administration law since the promulgation of the State Administration Law 30 of 2014. This research is a legal research with a conceptual approach, a legal approach. This research data is secondary data which includes primary legal documents, secondary legal documents and tertiary legal documents. As a consequence, Law Number 30 of 2014 concerning the Implementation of State Administrative Courts has made major changes to the absolute jurisdiction of the State Administrative Court, namely the absolute jurisdiction of the State Administrative Court. state administrative decisions (beschikking), accompanied by courts and complaints to the state administrative courts.
\end{abstract}

Key words: Competence; Judiciary; Administration

\begin{abstract}
Abstrak
Tujuan dari penelitian ini adalah untuk menjelaskan bidang hukum Peradilan Tata Usaha Negara sejak diundangkannya Undang-Undang Tata Usaha Negara Nomor 30 Tahun 2014. Penelitian ini merupakan penelitian hukum dengan pendekatan konseptual, pendekatan pendekatan hukum. Data penelitian ini merupakan data sekunder yang meliputi dokumen hukum primer, dokumen hukum sekunder dan dokumen hukum tersier. Akibatnya, UndangUndang Nomor 30 Tahun 2014 Tentang Penyelenggaraan Badan Tata Usaha Negara telah membuat perubahan besar terhadap wilayah hukum mutlak Peradilan Tata Usaha Negara, yaitu wilayah hukum mutlak peradilan Tata Usaha Negara. putusan tata usaha negara (beschikking), disertai penyalahgunaan kekuasaan dan pengaduan ke pengadilan tata usaha negara.
\end{abstract}

Kata kunci: Kompetensi; Peradilan; Administrasi

\section{PENDAHULUAN}

$$
\text { Tugas pemerintahan }
$$

dilaksanakan oleh pejabat pemerintah sesuai dengan kewenangannya dan sesuai dengan prinsip umum hukum dan pemerintahan yang baik. Segala kegiatan pemerintahan dilaksanakan oleh badan dan pejabat pemerintah yang melaksanakan tugas pemerintahan di bidang pemerintahan, legislatif, dan yudikatif, serta melaksanakan tugas pemerintahan lainnya sesuai dengan UUD 1945 dan/atau undang-undang. Demikian pula dalam UU No. 30 Tahun 2014 juga disebutkan bahwa pengertian pemerintahan yang digunakan adalah pemerintahan yang luas.

Undang-undang Nomor 30

Tahun 2014, sebagai ketentuan baru 
Barhamudin dan Abuyazid Bustomi, Perluasan Kompetensi Peradilan Tata Usaha Dalam Undang-Undang Administrasi Pemerintahan, Halaman 1-16

dari undang-undang penting di bidang hukum tata usaha negara, telah menjadi dasar hukum bagi pengadilan tata usaha negara untuk mengkaji dan memeriksa subyek litigasi. Peradilan Tata Usaha Negara memeriksa keputusan dan/atau tindakan badan atau pejabat TUN sesuai dengan peraturan perundang-undangan sesuai dengan Undang-Undang Nomor 30 Tahun 2014 tentang administrasi pemerintahan serta asas-asas umum pemerintahan yang baik.

Keputusan dan/atau tindakan lembaga yang ditujukan kepada masyarakat harus sesuai dengan ketentuan peraturan perundangundangan dan prinsip umum pemerintahan yang baik. Pengawasan hukum terhadap keputusan dan/atau tindakan lembaga merupakan ujian perlakuan terhadap masyarakat yang ditegakkan menurut undang-undang dan dilaksanakan secara efektif oleh pengadilan tata usaha negara yang bebas dan mandiri. Karena setiap penggunaan kekuasaan pemerintahan harus berdasarkan asas legalitas (rechmatigheid). Pengujian dari perspektif hukum atau dari perspektif rechmatigheid terutama fungsi kontrol yudisial yang dilakukan oleh pengadilan TUN. ${ }^{1}$ Oleh karena itu, berdasarkan uraian di atas, artikel ini bertujuan untuk menjelaskan bentuk kekuasaan mutlak peradilan TUN atas penyelenggaraan pemerintahan dalam mewujudkan prinsip-prinsip umum pemerintahan yang baik, dan menganalisis peran pengadilan tata usaha negara dalam membangun tata pemerintahan yang baik.

Penelitian ini dilakukan dengan tujuan untuk memberikan penjelasan yang lengkap terkait dengan kompetensi mutlak Peradilan Tata Usaha setelah diberlakukannya undang-und ang Administrasi Pemerintahan. Adapun manfaat yang diharapkan dari poenelitian ini adalah berkaitan dengan kompetensi mutlak peradilan Usaha Negara setelah diberlakukanna Undang-Undang Nomor 30 tahun 2014 tentang Administrasi Pemerintahan.

\section{METODE PENELITIAN}

Penelitian ini merupakan penelitian hukum normatif, dengan pendekatan konseptual (conceptual

\footnotetext{
1 Philipus. M. Hadjon et. al, Hukum Administrasi dan Good Governance (Jakarta: Universitas Trisakti, 2010).
} 
Barhamudin dan Abuyazid Bustomi, Perluasan Kompetensi Peradilan Tata Usaha Dalam Undang-Undang Administrasi Pemerintahan, Halaman 1-16

approach), pendekatan undang-undang (statute approach). ${ }^{2}$

Bahan hukum dikumpulkan melalui penelitian kepustakaan, yaitu untuk mencatat bahan hukum primer, bahan hukum sekunder dan bahan hukum tersier. Alat pengumpulan data merupakan pertanyaan yang perlu diperhatikan dalam setiap penelitian ilmiah, yaitu untuk memperoleh sumber penelitian yang benar dan bertanggung jawab. ${ }^{3}$ Penelitian ini dilakukan dengan penelitian kepustakaan untuk mendapatkan data sekunder yang terdiri dari:

1. Adapun yang dijadikan sebagai bahan hukum primer pada penelitian ini adalah peraturan perundangundangan yang berlaku, diantaranya Undang-Undang Nomor 5 Tahun 1986 Tentang Peradilan Tata UsahaNegara, UndangUndang Nomor 31 Tahun 1999 Tentang Pemberantsan Tindak

PidanaKorupsi, Undang-Undang Nomor. 9 Tahun 2004. tentang Perubahan Atas Undang-Undang Nomor 5. Tahun 1986. Tentang Peradilan Tata Usaha Negara,

2 Peter Mahmud Marzuki, Penelitian Hukum, Edisi Revisi (Jakarta: Kencana Prenada Media Group, 2014).

${ }^{3}$ Peter Mahmud Marzuki
Undang Undang Nomor 30 Tahun 2014

Tentang

AdministrasiPemerintahan.

2. Selanjutna yang menjadi bahan hukum sekunder dalam penelitian ini diantaranya adalah bentuk literatur-literatur Hukum Administrasi Negara, Hukum Acara Peradilan Tata UsahaNegara, Hukum Pidana, serta bahan-bahan lain khususnya yang memiliki relevansi pada topik permasalahan yang akan diteliti.

3. Seadangkan bahan hukum tersier yang digunakan dalam penelitian ini adalah diambil dari kamus, majalah, surat kabar, internet untuk penunjang informasi dalam penelitian.

Seluruh data yang sudah dikumpulkan, selanjutnya disusun, kemudian dianalisis dengan analisis kualitatif, dan untuk selanjutnya data yang diperoleh dianalisis dengan menggunakan metode induktif, yaitu dengan mencari aturan-aturan, nilainilai maupun norma-norma hukum yang kemudian ditarik kesimpulan.

\section{PEMBAHASAN}

Pengawasan hukum terhadap tindakan pemerintah dilaksanakan 
Barhamudin dan Abuyazid Bustomi, Perluasan Kompetensi Peradilan Tata Usaha Dalam Undang-Undang Administrasi Pemerintahan, Halaman 1-16

melalui Peradilan tata usaha negara, sementara itu terkait dengan perlindungan untuk pejabat pemerintahan di peradilan belum ditemukan aturan yang menjadi dasar hukumyna, oleh karenanya menyebabkan tidak jarang pejabat pemerintah mendapatkan sanksi konsekuwensi atas perbuatan yang telah dilakukannya tersebut yang menimbulkan tindakan penyalah gunaan wewenang. Dengan dimungkinkannya terjadi tindakan penyalahgunaan wewenang tersebut, maka diperlukan suatu lembaga peradilan yang berfungsi untuk memberikan penilaian tentang terdapatnya unsur-unsur penyalahgunaan wewenang yang terjadi akibat tindakan pejabat. Dalam hal perlindungan hukum terhadap pejabat pemerintah, telah ditetapkan pada undang-undang Administrasi pemerintahan, secara tegas diatur dalam Pasal 3 huruf (e) yaitu dalam hal memberikan pelayanan perlindungan hukum terhadap warga masyarakat serta aparatur pemerintahan. Dalam ketetapan Pasal 6 ayat (2) huruf ( I) juga dinyatakan bahwa pelaksana pemerintahan berhak dalam memperoleh pelayanan perlindungan hukum serta jaminan keamanan pada saat melaksanakan kewajiban yang dimilikinya.

Perlindungan hukum yang diberikan kepada pejabat pemerintah merupakan perlindungan hukum terhadap pejabat pemerintah supaya dalam pelaksanaan tugas pemerintahan yang dilakukannya sehari-hari pejabat itu tidak menemukan hambatan secara teknis serta tindakan pemerintahan yang dilakukan oleh pejabat akan terus berjalan. Perlindungan hukum terhadap pelaksana pemerintahan akan diberikan selama pejabatt tersebut pada saat melaksanakan tindakan atau menentukan suatu keputusan tetap sesuai dengan koridor hukum yang telah ditetapkan. Perlindungan hukum tersebut bisa dalam bentuk penyerahan kewenangan tertentu terhadap pejabat itu, pembantuan hukum dalam proses penyelesaian sengketa, kepastian hukum saat melakukan yang menjadi tugas atas jabatan administrasi negara. ${ }^{4}$ Terdapatnya suatu kebijakan yang memberikan hak terhadap Badan dan/atau pejabat pemerintahan dalam hal meminta permohonan terhadap pengadilan dalam menilai terdapat atau

\footnotetext{
${ }^{4}$ Kementerian PAN dan RB, Naskah Akademik Rancangan Undang-Undang Tentang Administrasi Pemerintahan
} 
Barhamudin dan Abuyazid Bustomi, Perluasan Kompetensi Peradilan Tata Usaha Dalam Undang-Undang Administrasi Pemerintahan, Halaman 1-16

tidak adanya unsur penyalah gunaan wewenang merupakan instrumen pembelaan terhadap badan dan/atau pelaksana pemerintahan yang telah diduga melaksanakan penyalah gunaan wewenang, selain itu pada konteks hukum pidana dapat dikatakan bahwa yang bersangkutan telah menjelma sebagai korban atas kriminalisasi suatu kebijakannya. Kriminalisasi yang dilakukan pada kebijakan-kebijakan yang dibuat oleh pejabat pemerintah akan bisa mengakibatkan berbagai jenis ketidak pastian hukum, bahkan pada kontkes yang lebih luas akan bisa menggangu hukum itu sendiri. Hal ini dikarenakan oleh telah mensuperiorkan salah satu aspek hukum (pidana) serta mempertegas fungsi dan peran yang semestinya dilakukan oleh aspek hukum yang lainnya, diantaranya hukum perdata maupun hukum administrasi negara serta aspek hukum lainnya. ${ }^{5}$

Dalam ketentuan UndangUndang Administrasi Pemerintahan ditetapkan dua pasal yang berbeda tentang Penyalah gunaan wewenang tersebut, yaitu aturan dalam Pasal 10

5 Tri CahyaIndra, Catatan Kritis Terhadap Perluasan Kewenangan Mengadili Peradilan Tata Usaha Negara (Yogyakarta: Genta Press, 2016). ayat (1) huruf e serta Pasal 17 ayat (2). Pada ketentuan Pasal 10 ayat (1) huruf e dikategorikan sebagai AUPB yakni asas tidak menyalahgunakan kewenangan, yang dapat diartikan sebagai "setiap instansi dan/atau pejabat pemerintah tidak menggunakan kekuasaannya untuk keuntungan pribadi atau keuntungan lain dan tidak sesuai dengan tujuan pemberiannya, tidak melebihi, menyalahgunakan dan/atau tidak mencampurkan kedua kekuasaan tersebut. Pasal 17 ayat 92) menyatakan beberapa hal yang dilarang yang apabila dilakukan termasuk pada penyalahgunaan Wewenang meliputi:

a. tidak boleh melakukan tindakan yang melampaui Wewenang dari pejabat tersebut;

b. tidak boleh melakukan tindakan yang mencampur adukkan Wewenang; serta

c. tidak boleh melakukan tindakan sewenang-wenang.

Menurut ketentuan dalam undang- undang Administrasi Pemerintahan, pelaksana pemerintahan yang melaksanakan tindakan penyalah gunaan wewenang mempunyai dampak yuridis, yakni apabila suatu keputusan dan/atau tindakan diambil oleh atasan yang berwenang atau bertindak 
Barhamudin dan Abuyazid Bustomi, Perluasan Kompetensi Peradilan Tata Usaha Dalam Undang-Undang Administrasi Pemerintahan, Halaman 1-16

sewenang-wenang, maka keputusan itu akan dinyatakan batal demi hukum setelah diperiksa dan suatu putusan pengadilan mempunyai kekuatan hukum tetap.Keputusan dan/atau tindakan yang diambil dengan mencampuradukkan wewenang dapat dibatalkan apabila telah diperiksa dan telah ada putusan pengadilan yang mempunyai kekuatan hukum tetap. Keputusan tata usaha negara yang dilembagakan di Peradilan Tata Usaha Negara selalu harus dinyatakan batal, dengan atau tanpa tuntutan dan/atau pemulihan.

Istilah pembatalan dipahami dalam konteks suatu keputusan yang bersifat ex nunc atau pro future, artinya keputusan itu berlaku di masa yang akan datang, artinya ketentuanketentuan hukum atau perbuatanperbuatan administratif dianggap efektif sampai dinyatakan batal. Sedangkan istilah tidak sah digunakan dalam konteks retroaktif atau keputusan sebelumnya. ${ }^{6}$ Keputusan yang menyatakan bahwa suatu ketentuan perundang-undangan tidak sah atau bahwa tindakan suatu instansi pemerintah dianggap tidak pernah ada

\footnotetext{
6 Irfan Fachruddin, Pengawasan Peradilan Administrasi Terhadap Tindakan Pemerintah (Bandung: Alumni, 2004).
}

dan tidak pernah merupakan perbuatan yang berkekuatan hukum, merupakan pernyataan dan bukan merupakan. Pada akhirnya, perbedaan antara ketentuanketentuan yang batal itu baru dipahami ketika Undang-Undang Administrasi Pemerintahan disahkan.

Konotasi tidak sah adalah suatu keputusan dan/atau tindakan yang ditetapkan dan/atau diambil oleh pejabat yang berwenang dan/atau pejabat yang tidak berwenang sehingga dianggap tidak pernah ada atau kembali seperti semula sebelum keputusan dan/atau tindakan tersebut ditetapkan dan/atau diterima dan segala akibat yang timbul darinya, oleh karena itu dianggap tidak pernah ada. Yang dimaksud dengan dapat dicabut adalah mencabut Keputusan dan/atau Perbuatan dengan cara pemeriksaan oleh Pengawas atau kekuasaan kehakiman. Adapun akibat hukum dari putusan yang telah diputus oleh pengadilan pemerintah tidak mengenal istilah ketidakabsahan, tetapi jangka waktu tersebut dapat dicabut. Ada pendapat lain bahwa arti dapat dibatalkan sama dengan arti pembatalan, yaitu akibat hukum suatu putusan dan akibat itu dianggap ada 
Barhamudin dan Abuyazid Bustomi, Perluasan Kompetensi Peradilan Tata Usaha Dalam Undang-Undang Administrasi Pemerintahan, Halaman 1-16

sampai putusan dijatuhkan oleh hakim. $^{7}$

Putusan PTUN tersebut bersifat istimewa karena putusan PTUN untuk menyelesaikan sengketa yang berkaitan dengan hukum publik, putusan PTUN tersebut akan mempunyai akibat hukum yang mengikat masyarakat dan mempunyai akibat hukum nilai litigasi. yang di kemudian hari terdapat persamaan yang mungkin timbul dengan putusan PTUN tentang hukum perdata yang mengikat para pihak yang bersengketa. ${ }^{8}$ Akibatnya, putusan PTUN mengikat masyarakat secara hukum, artinya putusan pengadilan berlaku bagi siapa saja, bukan hanya para pihak yang bersengketa. Sisi positif dari sifat erga omnes adalah adanya kepastian hukum mengenai letak perbuatan legislatif atau administratif yang dinyatakan batal demi hukum atau dicabut. Sedangkan sisi negatifnya berarti hakim tidak lagi menjalankan fungsi pembuatan undang-undang saja, tetapi telah berkembang untuk menjalankan fungsi pembuatan undang-undang. ${ }^{9}$ Oleh karena itu, putusan penyalahgunaan

${ }^{7}$ S. F. Marbun, Peradilan Administrasi Negara \& Upaya Administratif di Indonesia (Yogyakarta: Liberty, 1997).

${ }^{8}$ S. F. Marbun

${ }^{9}$ S. F. Marbun kendali tetap menghormati prinsip erga omnes. Esensi erga omnesnya dapat dilihat dalam Pasal 21 ayat (6) UU Administrasi Pemerintahan dan Pasal 21 ayat (2) Peraturan Mahkamah Agung Republik Indonesia No. 2015 tentang Pedoman Tata Tertib dalam penilaian. faktor penyalahgunaan kekuasaan, bahwa putusan Pengadilan Tata Usaha Negara dalam hal penyalahgunaan kekuasaan untuk menguji kekuasaan bersifat final dan mengikat.

Hukum Tata Usaha Negara mengatur bahwa seseorang dianggap menyalahgunakan kekuasaannya jika ia melakukan beberapa ketentuan Pasal 17 dan 18. Dalam Pasal 17, larangan terhadapnya menyalahgunakan kekuasaan dibagi menjadi tiga bagian, yaitu larangan menguasai kekuasaan. ; Larangan Percampuran Otoritas; dan/atau dilarang keras untuk bertindak sewenang-wenang. Sementara itu, Pasal 18 UU Administratif menjelaskan secara lebih rinci larangan tindakan override power; Larangan Percampuran Otoritas; dan/atau dilarang keras untuk bertindak sewenang-wenang. Isi pasal 17 ayat (2). Dalam Pasal 18 UndangUndang tentang Administrasi 
Barhamudin dan Abuyazid Bustomi, Perluasan Kompetensi Peradilan Tata Usaha Dalam Undang-Undang Administrasi Pemerintahan, Halaman 1-16

Pemerintahan disebutkan bahwa instansi dan/atau pejabat pemerintah tergolong melampaui kewenangan sebagaimana dimaksud dalam Pasal 17 ayat (2) huruf a jika dilakukan pengambilan keputusan dan/atau tindakan:

1. Melebihi dari jangka waktu jabatan maupun batas waktu berlakunya kewewenangan;

2. Melebihi batasan wilayah diberlakukannya Wewenang; serta

3. Berlawanan dengan apa yang telah ditentukan pada peraturan perundangan. Institusi dan/atau pelaksana Pemerintahan dapat dikategorikan sebagai mencampur adukkan kewenangan seperti melampaui jangka waktu sebagaimana dimaksud dalam Pasal 17 Ayat (2) huruf b jika suatu keputusan maupun tindakan yang dilakukan tersebut:

1. Keluar dari lingkup bidang atau substansi kewenangan yang diterima; dan/atau.,

2. Tidak bersesuaian dengan apa yang menjadi tujuan kewenangan yang diberikan tersebut.

Sementara istitusi maupun pelaksana Pemerintahan dapat dikategorikan sebagai melakukan tindakan kesewenang-wenangan sebagaimana ditetapkan pada Pasal 17

Ayat (2) huruf c jika Keputusan maupun Tindakan yang dilakukan tersebut:

1. Tidak memiliki dasar atas kewenangan; serta

2. Tidak bersesuaian pada Putusan Pengadilan yang telah memiliki kekuatan hukum tetap.

Selanjutnya suatu

tindakan/perbuatan dapat dijatuhi sanksi pidana ketika perbuatan/ tindakan tersebut telah memenuhi beberapa kriteria berikut:

1. Suatu perbuatan/tindakan dapat di pidana ketika perbuatan tersebut terbukti telah memiliki niat jahat (mens rea);

2. Terhadap suatu perbuatan jahat, apakah yang tergolong pada tindak pidana yang bersifat ringan maupun tindak pidana berat, maka dalam penerapan sanksi pidana harus selalu ditempatkan sebagai ultimum remedium (senjata terakhir) yakni jikalau sebelumnya telah dijatuhi sanksi hukum lain.

3. Perilaku ini tergolong perilaku buruk karena perilaku itu sendiri (evil in it self) dan pada hakikatnya merupakan pelanggaran moral dan norma sosial (mala in se). Misalnya, 
Barhamudin dan Abuyazid Bustomi, Perluasan Kompetensi Peradilan Tata Usaha Dalam Undang-Undang Administrasi Pemerintahan, Halaman 1-16

pembunuhan, pencurian, dan penipuan. Sedangkan jika perbuatan atau perbuatan pembuat undangundang tersebut termasuk tindak pidana seperti korupsi dan pencucian uang (mala prohibita atau malum prohibitum), hendaknya memperhatikan 3 (tiga) unsur dasar hukum, yaitu kepastian hukum (rechtssicherheit), keadilan. (zweckmassigkeit) dan keadilan (gerechtigkeit).

Setelah hukum tata usaha negara diundangkan, pelanggaran tata usaha negara yang merugikan keuangan negara belum tentu merupakan tindak pidana korupsi. Oleh karena itu, pejabat publik (ASN) yang diduga melanggar ketentuan administrasi melalui kesengajaan, kelalaian atau perbuatan yang tidak patut hanya akan menjadi tindak pidana korupsi jika ada niat jahat (mens rea), bukan karena jabatannya. Hal ini setelah melakukan prosedur penyelesaian hukum administrasi terlebih dahulu. ${ }^{10}$

Dalam hukum tata usaha negara, kesalahan penyelenggara negara dibagi menjadi tiga jenis, yaitu kesalahan

10 hukumonline.com/berita/26/01/2017/beginialasan-mk-ubah-delik-tipikor, diakses pada 11 Juli 12021. administrasi ringan, sedang, dan berat. Oleh karena itu, atas dasar asas yang merupakan upaya hukum terakhir dari hukum pidana, peraturan perundangundangan tata usaha negara perlu menciptakan kondisi bagi peraturan perundang-undangan tata usaha negara untuk menjalankan fungsinya sendiri terlebih dahulu, dalam hal kesalahan kecil, hukum tata usaha negara. Hukuman Hukum Administrasi mengatur hukuman untuk penyalahgunaan kekuasaan sebagai berikut: peringatan lisan; peringatan tertulis; atau, penundaan hak atas promosi, kasta dan/atau jabatan.

Bahwa apabila pejabat melakukan pelanggaran yang tergolong pelanggaran sedang, sanksi bagi penyalahgunaan kekuasaan sedang adalah: pembayaran paksa dan/atau restitusi; pemberhentian sementara dengan memperoleh hak resmi; atau, pemberhentian sementara tanpa wewenang resmi. Adapun penyalahgunaan kewewenangan administrasi dapat dikategorikan sebagai penyalahgunaan kewewenangan administrasi berat apabila:

1. Badan/ Pelaksanat Pemerintahan melakukan tindakan/perbuatan 
Barhamudin dan Abuyazid Bustomi, Perluasan Kompetensi Peradilan Tata Usaha Dalam Undang-Undang Administrasi Pemerintahan, Halaman 1-16

menyalahgunakan kewewenangan sebagaimana ditentukan dalam Pasal 17 Undang-Undang Administrasi Pemerintahan).

2. Badan/ Pelaksanat Pemerintahan membuat Keputusan yang memiliki konflik antar kepentingan, hal tersebut sebagaimana diatur dalam Pasal $42 \quad$ Undang-Undang Administrasi Pemerintahan).

Dalam ketentuan UndangUndang Nomor 30 Tahun 2014 ditentukan hukuman terhadap terjadinya Penyalah gunaan kewenangan yang berat berat yaitu:

1. Diberhentikan secara sementara namun tetap mendapatkan hak-hak serta fasilitas yang diterimanya selama ini;

2. Diberhentikan secara tetap dengan tidak mendapatkan hak-hak keuangan serta fasilitas yang diterimanya selama ini;

3. Diberhentikan secara tetap, namun tetap mendapatkan hak-hak keuangan serta fasilitas yang diterimanya kemudian diumumkan pada khalayak melalui media massa; atau,

4. Diberhentikan secara tetap dengan tidak mendapatkan hak-hak keuangan serta fasilitas lainnya kemudian diumumkan pada

khalayak melalui media massa.

Dalam ketentuan Pasal 20 dinyatakan, bahwa Pengawasan terhadap larangan penyalah gunaan kewenangan seperti ditentukan pada Pasal 17 dan Pasal 18 dilasanakan oleh tim pengawas internal pemerintahan, serta hasil dari pelaksanaan pengawasan oleh aparatur pengawasan internal pemerintah dapat berupa:

a. tidak ad anya suatu kesalahan;

b. ditemukan kesalahn secara administratif;

c. ditemukan kesalahan administratif, yang menyebabkan terdapatnya kerugian keuangan negara.

Jika keputusan Departemen Pengawasan Intern Pemerintah berupa: Tidak ada kesalahan; Telah terjadi kesalahan administratif; atau Apabila terjadi kesalahan administrasi yang mengakibatkan kerugian negara, maka harus segera dilaksanakan. Dalam hal Negara mengalami kerugian keuangan, maka harus dikembalikan dalam waktu 10 (sepuluh) hari setelah keputusan badan pengawasan intern Pemerintah diterbitkan. Jika lembaga atau pejabat pemerintah menolak keputusan Badan Pengawasan Intern Pemerintah (AIPP), maka ia dapat mengajukan 
Barhamudin dan Abuyazid Bustomi, Perluasan Kompetensi Peradilan Tata Usaha Dalam Undang-Undang Administrasi Pemerintahan, Halaman 1-16

permohonan ke pengadilan tata usaha negara untuk memverifikasi keaslian keberadaan atau tidak ada penyalahgunaan kekuasaan.

Berdasarkan Pasal 53 UU TUN, dalam hal terjadi dugaan penyalahgunaan wewenang oleh instansi/pejabat pemerintah, masyarakat berhak melaporkan dugaan penyalahgunaan wewenang tersebut kepada AIPP atau pejabat lain. kekuasaan. Dugaan penyalahgunaan tidak mengambil keputusan sesuai dengan hukum dan prinsip umum pemerintahan yang baik, masyarakat dapat mengajukan permohonan ke pengadilan tata usaha negara untuk keputusan menerima permintaan keputusan, keputusan dan/atau tindakan dari pemerintah atau bukan. Instansi atau pejabat pemerintah yang tidak menentukan keputusan dan/atau tindakan.

Dalam Kamus Besar Bahasa Indonesia pengertian kompetensi diartikan sebagai kewenangan (kekuasaan) untuk menentukan (memutuskan sesuatu). Dalam hukum, yurisdiksi juga bisa disebut yurisdiksi, dalam yudikatif berarti kewenangan pengadilan atau pengadilan yang memiliki kekuasaan untuk menyelesaikan sengketa tertentu sesuai dengan hukum.. ${ }^{11}$ Yurisdiksi absolut atau sering disebut juga dengan kewenangan absolut adalah kewenangan suatu kekuasaan kehakiman untuk memeriksa dan memutus perkara-perkara tertentu yang sama sekali tidak mungkin dilakukan oleh kekuasaan kehakiman yang lain, bahkan dalam suatu wilayah hukum yang sama, satu lingkungan persidangan atau dalam lingkungan yang berbeda. ${ }^{12}$ Jika ada putusan Pengadilan tentang suatu masalah yang sama sekali tidak cakap untuk mempertimbangkan dan mengambil keputusan, maka itu batal demi hukum. ${ }^{13}$

Sedangkan yurisdiksi relatif adalah kewenangan otoritas kehakiman yang serupa untuk mempertimbangkan dan mengadili suatu perkara berdasarkan kompetensinya. Yurisdiksi absolut atau yurisdiksi absolut didefinisikan sebagai kewenangan otoritas yudisial untuk

\footnotetext{
${ }^{11}$ M. Yahya Harahap, Hukum Acara Perdata Tentang Gugatan, Persidangan, Penyitaan, Pembuktian dan Putusan Pengadilan (Jakarta: Sinar Grafika. 2007).

12 Bambang Sutiyoso, Penyelesaian Sengketa Bisnis (Yogyakarta: Citra Media Hukum, 2006).

${ }^{13}$ Sri Wardah dan Bambang Sutiyoso, Hukum Acara Perdata Dan Perkembangannya di Indonesia (Yogyakarta: Gama Media, 2007).
} 
Barhamudin dan Abuyazid Bustomi, Perluasan Kompetensi Peradilan Tata Usaha Dalam Undang-Undang Administrasi Pemerintahan, Halaman 1-16

mempertimbangkan jenis kasus tertentu yang sama sekali tidak mungkin untuk dipertimbangkan oleh badan yudisial di lingkungan yudisial lainnya.. ${ }^{14}$

Dalam rangka memahami sepenuhnya tentang yurisdiksi mutlak Peradilan Tata Usaha Negara, hal ini harus dilakukan dengan melihat Undang-Undang Tata Usaha Negara dibandingkan dengan beberapa ketentuan undang-undang yang sudah diberlakukan sebelumnya, yakni diberlakukannya Undang-Undang Nomor 1986 tentang Peradilan Tata Usaha Negara, sebagaimana telah direvisi terakhir kali. menurut UndangUndang Nomor 51 Tahun 2009 tentang Peradilan Tata Usaha Negara. Jika mengutip Undang-Undang Nomor 5 Tahun 1986 bersama-sama dengan Undang-Undang Nomor 51 Tahun 2009 tentang Peradilan Tata Usaha Negara, maka kewenangan mutlak Peradilan Tata Usaha Negara adalah mengadili sengketa tata usaha negara antara orang perseorangan, badan hukum perdata atau orang dengan badan tata usaha negara/pejabat umum, sebagai akibat dari dikeluarkannya keputusan tentang Tata Usaha Negara.

14 Soedikno Mertokusumo, Hukum Acara Perdata Indonesia (Yogyakarta: Liberty, 1988).

\section{Dalam Undang-Undang}

Peradilan Tata Usaha Negara, yurisdiksi absolut terbatas pada putusan dan putusan atas sengketa tata usaha negara yang timbul karena dikeluarkannya putusan tata usaha negara, khususnya putusan keputusan tertulis yang bersifat pribadi dan pada akhirnya mempunyai akibat hukum bagi seseorang atau suatu badan hukum. ${ }^{15}$ Berdasarkan hal tersebut, untuk memahami undang- undang tentang penyelenggaraan negara, perlu terlebih dahulu mempertimbangkan dan memahami undang-undang yang telah berlaku sebelumnya, karena diundangkannya undang-undang Nomor 30 Tahun 201 tentang penyelenggaraan negara telah mengubah siapa yang memiliki kewenangan atau kekuasaan mutlak. Kewenangan lembaga penyelenggara negara. Untuk meneliti. Perubahanperubahan yang terjadi pada saat Undang-Undang Administrasi Negara diundangkan adalah sebagai berikut:16

\footnotetext{
15 Imam Soebechi et. al. Bunga Rampai Peradilan Administrasi Kontemporer (Yogyakarta: Genta Press, 2014).

16 Bambang Heriyanto, "Kompetensi Absolut Peradilan Tata Usaha Negara Berdasarkan Paradigma Undang-Undang Nomor 30 Tahun 2014 Tentang Administrasi Pemerintahan," Pakuan Law Review, Volume IV, Nomor 1, Januari-Juni 2018: 82 .
} 
Barhamudin dan Abuyazid Bustomi, Perluasan Kompetensi Peradilan Tata Usaha Dalam Undang-Undang Administrasi Pemerintahan, Halaman 1-16

1. diperluasanya pengertian tentang KATUN sebagaimana telah ditetapkan dalam Pasal 1 angka 7 Undang-Undang Administrasi Pemerintahan.

2. Kewenangan yang dimiliki oleh Peradilan Tata Usaha Negara dalam hal Tindakan administrasi pemerintahan /tindakan faktual pejabat TUN sebagaimana ditur dalam Pasal 1 angka 8.

3. Kewenangan Peradilan TUN kepada Pengujian terhadap terdapat atau tidak terdapatnya tindakan penyalah gunaan kewewenangan dalam penerbitan Keputusan Tata Usaha Negara.

4. Kewenangan Peradilan TUN dalam hal memutus terhadap suatu obyek sengketa yang fiktif positif sebagaimana dadam Pasal 53 Undang-Und ang Administrasi Pemerintahan.

Ketentuan yang terdapat pada Pasal 53 Undang-Undang Administrasi Pemerintahan ditetapkan bahwa :

1. Jangka waktu kewajiban dalam hal menetapkan dan/atau membuat suatu Keputusan maupun Tindakan yang disesuaikan dengan ketetapan peraturan perundang-undangan.
2. Apabila dalam ketentuan peraturan perund ang-undangan tidak ditentukan batasan waktu kewajiban sebagaimana ditetapkan dalam ayat (1), selanjutnya Badan dan/atau Pejabat Pemerintahan diwajibkan menetapkan dan/atau melakukan Keputusan dan/atau Tindakan dalam waktu paling lama 10 (sepuluh) hari kerja setelah permohonan diterima secara lengkap oleh Badan dan/atau Pejabat Pemerintahan.

3. Apabila dalam jangka waktu sebagaimana dimaksud pada ayat (2), instansi dan/atau wakil pemerintah tidak dapat menetapkan dan/atau melaksanakan suatu keputusan dan/atau tindakan, maka permintaan tersebut dianggap dapat diterima secara yuridis.

4. Pemohon mengajukan permohonan kepada Pengadilan untuk memutuskan diterimanya permohonan sebagaimana dimaksud pada ayat (3).

5. Pengadilan memutuskan gugatan sebagaimana dimaksud pada ayat (4) paling lambat 21 (dua puluh satu) hari kerja sejak tanggal permohonan diajukan.

6. Instansi dan/atau pejabat pemerintah wajib menyelenggarakan 
Barhamudin dan Abuyazid Bustomi, Perluasan Kompetensi Peradilan Tata Usaha Dalam Undang-Undang Administrasi Pemerintahan, Halaman 1-16

pemberlakuan putusan Pengadilan sebagaimana dimaksud pada ayat (5) paling lambat 5 (lima) hari kerja sejak tanggal ditetapkannya putusan Pengadilan.

Isu penyalahgunaan kekuasaan menjadi topik pembicaraan penting karena dengan diundangkannya Undang-Undang Tata Usaha Negara Nomor 30 Tahun 2014, kewenangan Peradilan Tata Usaha Negara adalah menguji undang-undang tersebut. kekuasaan dalam membentuk keputusan-keputusan administratif negara. Pasal 21 Hukum Tata Usaha Negara mengatur:

1. Pengadilan memiliki kekuasaan untuk menerima, meninjau dan memutuskan apakah ada unsur penyalahgunaan kekuasaan oleh pejabat pemerintah.

2. Instansi dan/atau pejabat pemerintah dapat mendatangi Pengadilan untuk menentukan apakah ada unsur penyalahgunaan kekuasaan dalam suatu keputusan dan/atau tindakan.

Undang-undang yang mengatur tentang pemerintahan ini merupakan payung hukum bagi aparatur pemerintah dalam menjalankan kekuasaannya, apalagi mengingat situasi sosial yang sangat dinamis dan terkadang memerlukan keputusan yang cepat. Namun sayangnya, penyalahgunaan kekuasaan seringkali dipahami sebagai penyalahgunaan fasilitas dan kesempatan, yang bertentangan dengan undang-undang (werrechtelijkheid, onrechtmatige daad), atau bahkan meluas ke segala tindakan yang melanggar peraturan perundang-undangan, aturan atau kebijakan dan dalam bidang apapun. . Dengan penggunaan konsep ini secara luas dan liberal, maka dengan mudah menjadi senjata bagi para penyalahguna kekuasaan lainnya, dan justru kebebasan ini mengatur bagaimana seseorang menyalahgunakan kekuasaan, kesempatan, atau kekuasaan, atau fasilitas yang tersedia bagi mereka karena kedudukan atau kedudukan yang dapat merugikan. keuangan negara atau perekonomian negara.. ${ }^{17}$

Penyerahan kepada pejabat yang berwenang mutlak atau kewenangan mutlak badan tata usaha negara untuk mempertimbangkan ada tidaknya penyalahgunaan kekuasaan dalam penerbitan keputusan tata usaha negara, peraturan dalam Pasal 21

\footnotetext{
17 Supandi. Hukum Peradilan Tata Usaha Negara (Bandung: Alumni, 2016).
} 
Barhamudin dan Abuyazid Bustomi, Perluasan Kompetensi Peradilan Tata Usaha Dalam Undang-Undang Administrasi Pemerintahan, Halaman 1-16

KUHAP, di bawah yurisdiksi absolut. kewenangan Pengadilan Tata Usaha Negara. Hal ini terlihat dalam penafsiran pengertian pengadilan dalam pasal 21 yang dijelaskan dalam ketentuan pasal 1 dan 18 kode yang sama, yaitu peradilan tata usaha negara. Pasal 21 Ayat (1) UU Tata Usaha Negara mengatur bahwa Mahkamah berwenang menerima, mempertimbangkan, dan memutuskan ada tidaknya unsur penyalahgunaan kekuasaan oleh penyelenggara negara. Pemberdayaan ini merupakan cerita baru dalam peradilan administrasi publik karena diberikan dalam bentuk undang-undang, karakter perkaranya adalah permintaan dan diajukan oleh suatu lembaga atau pejabat negara.

Dengan demikian, ternyata ketentuan Pasal 21 Ayat (1) UndangUndang Nomor 30 Tahun 201 dianggap telah merampas hak penyidik untuk melakukan penyidikan guna menentukan ada tidaknya penyalahgunaan wewenang penyidik. tersangka sebagai tersangka. pejabat pemerintah yang mereka yakini harus diselidiki. harus diperiksa terlebih dahulu di Pengadilan Tata Usaha Negara. ${ }^{18}$

Diundangkannya UndangUndang Pemerintah tentang Tata Usaha Negara Nomor 30 Tahun 201 merupakan era baru dimana undangundang pada hakekatnya dibentuk dalam suatu undang-undang tersendiri dengan berlakunya undang-undang tersebut. Sebelumnya, Undang-Undang Nomor 5 Tahun 1986 tentang Peradilan Tata Usaha Negara, direvisi dua kali dengan Undang-Undang Nomor 9 Tahun 200 dan Undang-Undang Nomor 51 Tahun 2009, yang mengatur tiga pasal, yaitu hak kebendaan, hukum pidana, badan tata usaha negara, dan yurisdiksi. . Saat ini, yurisdiksi absolut PTUN telah berkembang dari yang semula terbatas pada putusan TUN (beschikking), menjadi peningkatan penyalahgunaan kekuasaan dan Peninjauan kembali PTUN.

\section{KESIMPULAN}

Undang-undang Nomor 30 Tahun 201 tentang Penyelenggaraan Pemerintahan, telah membuat perubahan besar terhadap yurisdiksi

${ }^{18}$ Supandi, "Undang-Undang Nomor 30 Tahun 2014 Tentang Administrasi Pemerintahan Relevansinya Terhadap Disiplin Penegakan Hukum Administrasi Negara dan Penegakan Hukum Pidana,"Makalah. 
Barhamudin dan Abuyazid Bustomi, Perluasan Kompetensi Peradilan Tata Usaha Dalam Undang-Undang Administrasi Pemerintahan, Halaman 1-16

absolut peradilan tata usaha negara, yaitu. Saat ini kewenangan mutlak yudikatif tata usaha negara telah berkembang dari yang semula terbatas pada keputusan tata usaha negara (beschikking), menjadi semakin penyalahgunaan kekuasaan dan ajudikasi di pengadilan tata usaha negara.

\section{DAFTAR PUSTAKA}

Bambang Heriyanto, "Kompetensi Absolut Peradilan Tata Usaha Negara Berdasarkan Paradigma Undang-Undang Nomor 30 Tahun $2014 \quad$ Tentang Administrasi Pemerintahan," Pakuan Law Review, Volume IV, Nomor 1, Januari-Juni 2018: 82.

Bambang Sutiyoso, Penyelesaian Sengketa Bisnis, Yogyakarta: Citra Media Hukum, 2006.

hukumonline.com/berita/26/01/2017/be gini-alasan-mk-ubah-deliktipikor, diakses pada 11 Juli 1 2021.

Imam Soebechi et. al. Bunga Rampai Peradilan Administrasi

Kontemporer, Yogyakarta: Genta Press, 2014.

Irfan Fachruddin, Pengawasan Peradilan Administrasi

Terhadap Tindakan Pemerintah, Bandung: Alumni, 2004.

Kementerian PAN dan RB, Naskah Akademik Rancangan Undang-
Undang Tentang Administrasi Pemerintahan.

M. Yahya Harahap, Hukum Acara Perdata Tentang Gugatan, Persidangan, Penyitaan, Pembuktian dan Putusan Pengadilan, Jakarta: Sinar Grafika. 2007.

Peter Mahmud Marzuki, Penelitian Hukum, Edisi Revisi, Jakarta: Kencana Prenada Media Group, 2014.

Philipus. M. Hadjon et. al, Hukum Administrasi dan Good Governance, Jakarta: Universitas Trisakti, 2010.

S. F. Marbun, Peradilan Administrasi Negara \& Upaya Administratif di Indonesia, Yogyakarta: Liberty, 1997.

Soedikno Mertokusumo, Hukum Acara Perdata Indonesia, Yogyakarta: Liberty, 1988.

Sri Wardah dan Bambang Sutiyoso, Hukum Acara Perdata Dan Perkembangannya di Indonesia, Yogyakarta: Gama Media, 2007. Supandi. Hukum Peradilan Tata Usaha Negara, Bandung: Alumni, 2016. Supandi, "Undang-Undang Nomor 30 Tahun $2014 \quad$ Tentang Administrasi Pemerintahan Relevansinya Terhadap Disiplin Penegakan Hukum Administrasi Negara dan Penegakan Hukum Pidana," Makalah.

Tri CahyaIndra, Catatan Kritis Terhadap Perluasan Kewenangan Mengadili Peradilan Tata Usaha Negara, Yogyakarta: Genta Press, 2016. 